\title{
Original
}

\section{Sociodemographic characteristics of patients with chronic headache}

\author{
Características sociodemográficas dos pacientes portadores de cefaleia crônica
}

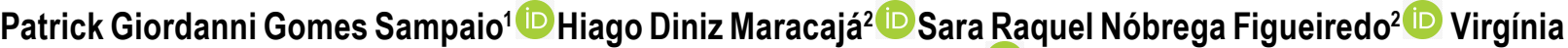 Gabriela Nóbrega Figueiredo 2 (iD) Túlio Carneiro Monteiro Temoteo ${ }^{2}$ (iD Nátalia Meg Adijuto de Melo²}

${ }^{1}$ Neuroconfiance, Neurologia, Campina Grande, Paraíba, Brazil. ²Unifacisa, Medicina, Campina Grande, Paraíba, Brazil.

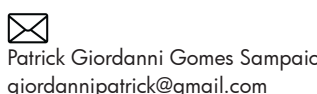

giordannipatrick@gmail.com

Edited by

Mario Fernando Prieto Peres

\section{Keywords: \\ Chronic Headache \\ Migraine}

Painkillers

\section{Palavras-chave:}

Transtornos da Cefaleia

Transtornos de Enxaqueca Analgésicos

\begin{abstract}
\section{Introduction}

Headache is an entity characterized by a painful process in the cephalic segment and may originate from cranial or facial structures, being considered a common medical complaint. The chronification process of the pain can present a decrease in quality, the functional capacity and the patient's and labor environment, and also as well as affect their interpersonal relationships, since the chronic cephalalgic process can lead the patient to moments of social isolation, mood swings, depression.

Methods

The research was conducted through a retrospective cross-sectional study, performing the analysis of medical records of patients seen at the Unifacisa's outpatient neurology School Clinic complaining of chronic headache, from February 1st to August 31, 2019.

Results

With the analysis of the medical records, 684 attendances were obtained, where 30 of the patients treated had the diagnosis of chronic headache, 29 women and 01 man. These patients received the following diagnoses: 18 (60\%) patients with chronic migraine without aura, 4 (13.3\%) patients with chronic migraine with aura, $12(40 \%)$ patients with chronic daily medication overuse headache, $9(30 \%)$ patients with chronic tensiontype headache (CTTH), 1 (3.3\%) patient with basilar migraine, 2 (6.6\%) patients with secondary headache.

\section{Conclusion}

Although a small number of chronic headache patients were obtained, yet we realize that it is the migraine that leads to a greater demand for specialized medical care. In addition, as expected due to the latest research, a significant number of patients with headache due to excessive use of common painkillers.
\end{abstract}

\section{Resumo}

\section{Introdução}

Cefaleia é uma entidade caracterizada por um processo doloroso no segmento cefálico, podendo ter origem em estruturas cranianas ou faciais, sendo considerada a queixa médica mais comum. $O$ processo de cronificação da dor pode apresentar uma diminuição na qualidade, da capacidade funcional e laboral do paciente, assim como, também, afetar nas suas relações interpessoais, haja visto que o processo cefalálgico crônico pode levar o paciente a momentos de isolamento social, mudanças de humor, depressão.

\section{Métodos}

A pesquisa foi realizada através de um estudo transversal retrospectivo, realizando a análise de prontuários de pacientes atendidos no ambulatório de neurologia da Clínica Escola da Unifacisa com queixa de cefaleia crônica, de $1^{\circ}$ de Fevereiro a 31 de Agosto, de 2019.

\section{Resultados}

Com a análise dos prontuários, obtevese a quantidade 684 atendimentos, onde 30 dos pacientes atendidos tinha o diagnóstico de cefaleia crônica, sendo 29 mulheres e 01 homem. Estes pacientes, receberam os seguintes diagnósticos: migrânea crônica sem aura $60 \%$, migrânea crônica com aura $13,3 \%$, cefaleia crônica diária por uso excessivo de analgésicos 40 \%, cefaleia do tipo tensional crônica (CTT) 30\%, enxaqueca basilar 3,3\%, cefaleia secundária 6,6\%.

\section{Conclusão}

Apesar de ter sido obtido um número pequeno de pacientes com cefaleia crônica, ainda assim, percebemos que são as migrâneas que levam a uma maior procura por atendimento médico especializado. Além disso, constatou-se, como esperado devido as mais recentes pesquisas, um número expressivo de pacientes portadores de cefaleia por uso excessivo de analgésicos comuns. 


\section{Introduction}

$\mathrm{H}$ eadache is an entity characterized by a painful process in the cephalic segment, may originate from cranial or facial structures, being considered a common medical complaint ${ }^{1,2}$. This may also occur episodically or chronically and may be classified in primary or secondary.

Chronic headache may be associated with several reasons, one of them being the abusive use of painkillers. Abusive use is characterized by the use of simple analgesics for 15 days or more in a month or, for triptans, ergotamines, opioids, caffeine and combined painkillers for 10 or more days in a month ${ }^{3 \cdot 5}$.

In addition, one can list as risk factors for the painfull process chronification in the cephalic region: ineffective treatment of headache, obesity, psychiatric disorders, being female, low education, daily stresses 6 . In this perspective, besides the clinical diagnosis of headache type, it is of extreme importance to identify the potential comorbidities that are chronifying factors, aiming at treating them and thus avoiding the aggravation of chronification.

Thus, it was noted the need to analyze the epidemiological profile of patients attended at the Unifacisa's outpatient neurology clinic. Mainly to determine if the demand for attendance occurs by following the global epidemiological pattern or another, as well as generating knowledge about the patients' own profile attended in this service.

\section{Material and Methods}

The research was conducted through a retrospective cross-sectional study, performing the analysis of medical records of patients seen at the Unifacisa's outpatient neurology School Clinic complaining of chronic headache, from February 1st to August 31, 2019, following the classification criteria of the International Classification of Headaches Disorders (ICHD-3). All patients were included, regardless of gender or age, that met criteria for chronic headache, whether primary or secondary, being excluded all patients who had headache but did not meet the ICHD-3 chronification criterion or had not yet received a diagnosis of headache.

\section{Results}

With the analysis of the medical records from February to August 2019,684 attendances were obtained, where 30 of the patients treated had the diagnosis of chronic headache, 29 women and 1 man. As for the profession, most were health care professionals, teachers and students. These patients received the following diagnoses: 18 (60\%) patients with chronic migraine without aura, 4 (13.3\%) patients with chronic migraine with aura, $12(40 \%)$ patients with chronic daily medication overuse headache, 9 (30\%) patients with CTTH, 1 (3.3\%) patient with basilar migraine, $2(6.6 \%)$ patients with secondary headache. Some of these patients received a diagnosis combination of chronic migraine or CTTH plus a chronic daily headache due to excessive painkillers.

\section{Discussion}

Chronic headache is defined when an individual who has a cephalalgic process that happens for at least 15 days in a month in 3 or more months in the year and may, in the case of migraine processes, meet chronification criteria with only 8 days of pain per month at 3 or more months in the year ${ }^{4-5,8}$.

It is also possible to subdivide the main etiologies of chronic headache: Transformed Migraine (TM), Chronic Tension-Type Headache (CTTH), New Daily Persistent Headache and continuous hemicranial $(\mathrm{CH})^{8}$.

One of the main causes of the chronic headache process is the abusive use of common painkillers or symptomatic drugs such as triptans, ergotamines, opioids, and it is estimated that $50 \%$ of patients who have a headache self-medicate. What leads to an estimate in Latin America that 55-70\% of patients that look for specialized centers due to headache, receive the diagnosis of medication overuse headach $\epsilon^{5}$.

According to the World Health Organization's Global Burden of Disease, migraine is the second leading cause of disability among all diseases, falling behind only mental disorders. Among people with migraine, within one year, $25 \%$ presented the same in episodic form, while $40 \%$ will oscillate between chronic and episodic ${ }^{5}$.

"Episodic tension-type headache is the most common of primary headaches, with peak prevalence in the fourth decade. In Brazil, the annual prevalence of migraine is $15.8 \%$, affecting about $22 \%$ of women and $9 \%$ of men, with peak prevalence between 30 and 50 years. Migraine without aura (75\% of cases) is more frequent than with aura (25\% of cases)". (Speciali et al. 2018)

Due to the incapacitating process of chronic headaches, individuals affected by this disease tend to have, besides the loss of capacity or productivity, problems of a personal and social nature, generated by the painful process that tends to cause isolation, depression, seclusion $^{6-8}$.

\section{Conclusion}

Although a small number of chronic headache patients were obtained, since headache is one of the major medical complaint and the highest prevalence of CTTHs in the general population, yet we realize that it is the migraine that leads to a greater demand for specialized medical care. Therefore, it is evident how migraines compromise both the functionality of the individual, as well as the quality of life. Moreover, the high and disproportionate prevalence of females over males, evading epidemiological patterns for headache, is supposed 
to be due to lower male demand for medical appointments, as well as fewer referrals from primary health care to more specialized centers. In addition, as expected due to the latest research, a significant number of patients with medication overuse headache. Thus, it becomes evident the importance of the early diagnosis clinical treatment, in addition to optimal drug treatment and population's awareness of the use of painkillers in order to reduce the prevalence of headaches caused by their abuse.

The small number of chronic headache care, about $4.32 \%$, was attributed to Unifacisa's school clinic care model. It is in a metropolitan region and is a reference for the specialized care of the surrounding city areas where there is often inadequate screening and the complaints of headaches are not referenced appropriately.

Thus, it is noted that the need to better track patients with complaints of headache and make the service more visible so that more and more patients can reach the most specialized centers and receive the most appropriate service for their complaints, thus reducing headaches related comorbidities.

\section{References}

1. Nitrini RA, Bacheschi LA. Neurologia Que Todo Médico Deve Saber. 3rd. São Paulo: Atheneu; 2015. 289-306p. Brazilian Portuguese.

2. Puledda F, Messina R, Goadsby PJ. An update on migraine: current understanding and future directions. Journal of Neurology. 2017; 264(9): 2031-2039.
3. Diener HC, Holle D, Dresler T, Gaul C. Chronic headache due to overuse of analgesics and anti-migraine agents. Deutsches Aerzteblatt Online. 2018; 115: 365-70.

4. Headache Classification Committee of the International Headache Society (IHS) The International Classification of Headache Disorders, 3rd edition. Cephalalgia. 2018; 38(1): 1- 211.

5. Kowacs F, Roesler CAP, Piovesan ÉJ, Sarmento EM, Campos HC, Maciel Júnior JA, et al. Consensus of the Brazilian Headache Society on the treatment of chronic migraine. Arquivos de Neuro-Psiquiatria. 2019; 77(7): 509-520.

6. May A, Schulte LH. Chronic migraine: risk factors, mechanisms and treatment. Nature Reviews Neurology. 2016; 12(8): 455-464.

7. Del Monaco R. Migraña y (des)encuentros: encierros y relaciones vinculares a partir de dolores de cabeza crónicos. Cuadernos de antropología social. 2015 July 30; 41: 109-127. Spanish.

8. Cho S, Song T, Chu MK. Outcome of Chronic Daily Headache or Chronic Migraine. Curr Pain Headache Rep 20, 2 (2016). https://doi.org/10.1007/s11916-015-0534-8

9. Speciali JG, Kowacs F, Jurno ME, Bruscky IS, Carvalho JJF, Fantini FGMM, et al. Protocolo Nacional Para Diagnóstico E Manejo Das Cefaleias Nas Unidades De Urgência Do Brasil - 2018. Academia Brasileira De Neurologia (Departamento Científico De Cefaleia) \& Sociedade Brasileira de Cefaleia. 2018. https:// sbcefaleia.com.br/images/file\%205.pdf . Brazilian Portuguese. 